DOI: http://doi.org/10.21698/simi.2018.fp49

\title{
MICROSTRUCTURAL AND CHEMICAL CHARACTERIZATION OF SOME WASTES FOR PHONOABSORBANT MATERIALS OBTAINING
}

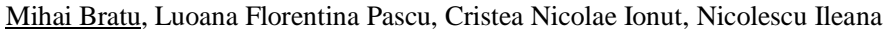

National Research and Development Institute for Industrial Ecology - ECOIND, 71-73

Drumul Podu Dambovitei, district 6, 060652, Bucharest, poluare.aer@incdecoind.ro, Romania

\begin{abstract}
Composite materials obtaining, based on wastes mixing, can have both, economical and social positive impact, and also the use of such composites materials leads to a level of environmental pollution reduction, generally, and in the level of noise pollution, particulary. This aim of this study is essential for the future development of such materials because, the results will give us informations regarding the formulation of oxide and polymeric composite materials, by associating the components and leads us to superior properties products, having the property to absorb sound waves. In this paper we characterize a number of wastes that are resulting from industrial technological processes. The wastes are characterized by granulometry, oxide composition and apparent porosity that are specific properties for obtaining composite materials with sound-absorbing properties.
\end{abstract}

Keywords: apparent porosity, granulometry, oxide composition, sound-absorbing properties, wastes

\section{Introduction}

The increase of the world population related with human activities from the last century, esspecially from industry and transports, have lead to an accentuate deterioration of the environmental air, with significant effects on climate, affecting the environment and also human health (Bucur \& Danet 2016, Danciulescu et al 2015, Minghua et al 2009, Petrescu et al 2017). This paper have an great importance theme with economic and ecological impact regarding the different wastes use which by their storage can affect the quality of the environment, in order to obtain composite materials with sound absorbing properties. Thus, two interest objectives will be achive, based on that study, namely the reduction of environmental pollution through the reuse of various wastes and the reduction of the noise pollution. One of the many environmental problems threatening our planet, a major one is, without a doubt, wastes (Lilliana et al 2013). These wastes are resulting from multiple human activities, and are representing an issue due to the continuous increase of the quantities and of their types (which by natural degradation can represent a danger for the environment and the population health) as well as the significant quantities of reusable materials and energy, that can be recovered and entered into the economic circuit (Serbanescu et al 2017, Guta et al 2017). National Rules in waste management domain must be adapted to General European Reglementations regarding the prevention of generate wastes and reducing resource consumption and practical aplication of wastes hierarchy (Danciulescu et al 2017, Directive 2008/98, Emergency Ordinance 195/2005, Law 211/2011). 


\section{INTERNATIONAL SYMPOSIUM "THE ENVIRONMENT AND THE INDUSTRY", SIMI 2018, PROCEEDINGS BOOK}

Studied wastes from this paper are made from organical or anorganical matter (oxidic wastes) such us: wooden wastes, thermal plants fireplace slag, domestic sterile wastes, sunflower husks seeds ash and metallic waste smelting slag (Figure 1). The aim is to obtain composite materials with sound absorbing properties by combining selected wastes with the oxide matrix - binder matrix obtained from selected and activated $\mathrm{CaCl}_{2}+\mathrm{CaO}$ (Bratu et al 2016, Stoleriu \& Teoreanu 2006, Stoleriu et al 2004, Teoreanu et al 2005, Teoreanu \& Stoleriu 2002) wastes or polymeric matrix and therefore the selected wastes are characterized in terms of granulometric distribution, oxidative composition and apparent porosity, important physical properties for phonoabsorbent composites.

\section{Materials and Methods}

Firstly the wastes used for studing in this project were dried, in accordance with in force standard (SR ISO 5264-1995). Total humidity was determined by summing the of Wî ibibation humidity and of Wh hygroscopic humidity, according to the ecuation (1), and the resulting values are shown in the Table 1.

$$
W_{t}=W_{\hat{\imath}}+W_{h}
$$

where: $\mathrm{W}_{\hat{\mathrm{r}}}$ - inbibation humidity; $\mathrm{W}_{\mathrm{h}}$ - hygroscopic humidity

Table 1. Total humidity for studied wastes

\begin{tabular}{c|cc}
\hline $\begin{array}{c}\text { Sample } \\
\text { No. }\end{array}$ & Wastes & $\begin{array}{c}\text { Total humidity } \\
\mathrm{W}_{\mathrm{t}}(\%)\end{array}$ \\
\hline S1 & Wooden waste & 36.42 \\
\hline S2 & Thermal plants fireplace slag & 48.75 \\
\hline S3 & Thermal plants ash & 53.20 \\
\hline S4 & Sunflower husks seeds ash & 55.44 \\
\hline S5 & Metallic waste smelting slag & 50.02 \\
\hline S6 & Domestic sterile wastes & 49.86 \\
\hline
\end{tabular}

After drying, large grain wastes were grinded (thermal and metallic waste smelting slag) according to in force standard (SR ISO 2591-1: 2003). The drying process was necesary esspecialy due to storage conditions of these materials.

Secondly the selected wastes used in this paper were analyzed in terms of granulometric distribution by sifting for the coarse fraction, as the case may be, for wooden waste, thermal plants fireplace slag, domestic sterile wastes, thermal plants slag, thermal plants ash, sunflower husks seeds ash, metallic waste smelting slag according to in force standard (SR EN-933-1:2002). The sifting operation was carried out with the Verder A5200 basic device, which can fit up to 8 sites. Fine fractions were identified using the MALVERN MASTERSIZER 2000 laser beam granulator (SR ISO 13320-1: 2001). All of these wastes were monitored to have a well-controlled granulometric distribution to ensure the reproducibility of all the data obtained. XRF analyzes were performed using a Rigaku Gas Cromatography analyzer (Rigaku, Japan) equipped with a 50W - X-ray source with a Pd anode. Detection was performed using a silicon drift detector (SSD) maintained at optimal temperature via a Peltier system. To perform the samples, the internal calibration was performed initially. Samples were pre-calcined at $550{ }^{\circ} \mathrm{C}$ and homogenized and then analyzed (SR 15309:2007). Samples representing the waste selected for the 


\section{INTERNATIONAL SYMPOSIUM "THE ENVIRONMENT AND THE INDUSTRY", SIMI 2018, PROCEEDINGS BOOK}

production of composite materials with phonoabsorbant properties were also analyzed in terms of apparent porosity.

Porosity determination was performed according with SR EN 993-1:1997. Thus, a portion of each waste sample was initially weighed $\left(\mathrm{mi}_{\mathrm{i}}\right)$, then in water immersed, after which weighed the mass $\left(\mathrm{m}_{\mathrm{f}}\right)$.

The apparent porosity $\left(n_{a}\right)$ is determined with the (2) relation:

$$
n_{a}=\left(m_{f}-m_{i}\right) / \rho_{l} \quad(\%)
$$

where: $m_{f}$ - final mass ; $m_{i}$ - initial mass ; $\rho_{\mathrm{l}}$ - density of the liquid

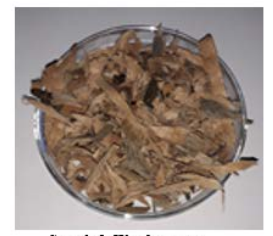

Sample 1-Wooden waste

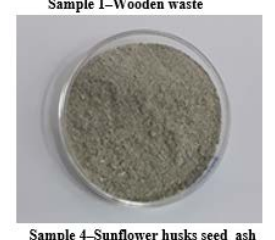

Sample 4-Sunflower husks seed ash
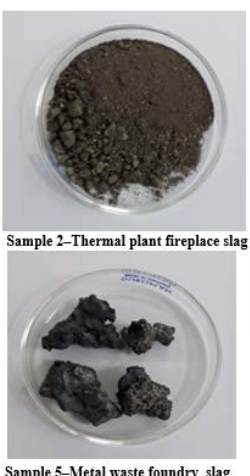

Sample 5-Metal waste foundry slag

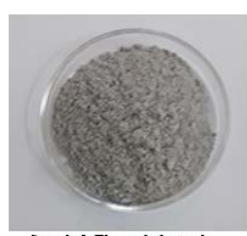

Sample 3-Thermel plant ash

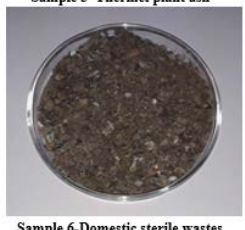

Figure 1. Images for analised waste samples

\section{Results and Discussion}

\section{S1-Wooden waste}

Wooden waste are the result of making wooden boards. The dimensions of the shanks are different: ranging from $0.1 \mathrm{~mm}$ to $15 \mathrm{~mm}$ as seen in Figure 2. The siving was performed at $0.25,0.5,2$, and $4 \mathrm{~mm}$.

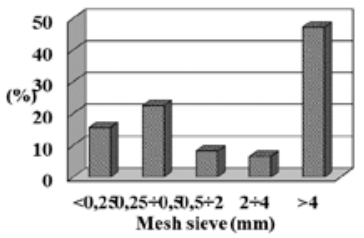

Figure 2. Granulometric distribution of wooden shanks waste

From the mass of material suposed to the granulometric analysis, different proportions were obtained as follows: remaining on the $4 \mathrm{~mm}$ sieve - the qantity of $47.2 \%$; between $2 \div 4 \mathrm{~mm}$ the remaining quantity was $6.5 \%$; between $0.5 \div 2 \mathrm{~mm}$ the remaining quantity was $8.2 \%$; between $0.25 \div 0.5 \mathrm{~mm}$ the remaining quantity was $22.5 \%$; sieved through $0.25 \mathrm{~mm}$ the ramaining quantity was $15.6 \%$. Thus, a large proportion of the material representing the wood shanks remaining on the $4 \mathrm{~mm}$ sieve is observed. The distribution of the varied granulometric distribution of this waste, with very few fine fractions and a large proportion of coarse fractions over 


\section{INTERNATIONAL SYMPOSIUM "THE ENVIRONMENT AND THE INDUSTRY", SIMI 2018, PROCEEDINGS BOOK}

$4.00 \mathrm{~mm}$ (almost 47.2\%), can condition the formation of a non-homogeneous structure of the reinforced composite with variable porosity and very large pores alternately with small pores.

\section{S2-Thermal plants fireplace slag and S3-thermal plants ash}

Most of the thermal power plants operate with solid fuel and the result of the combustion process is the combustion slag and the ash of the thermal plant. Figures 3a and $3 \mathrm{~b}$ show the granulometric distributions of coarse fractions (Figure 3a for slag) and fine fractions (Figure $3 b$ for thermal ash). Figure 4 also shows the oxide composition for these types of waste.

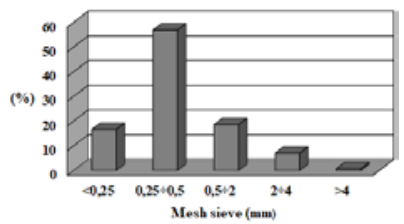

(a)

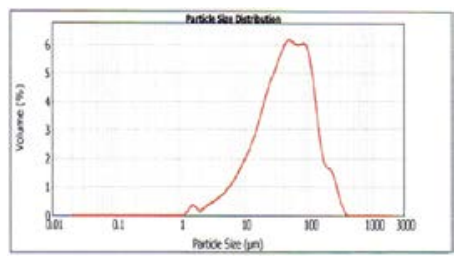

(b)

Figure 3. Granulometric distribution of thermal plants fireplace slag (a) and thermal plants ash (b)

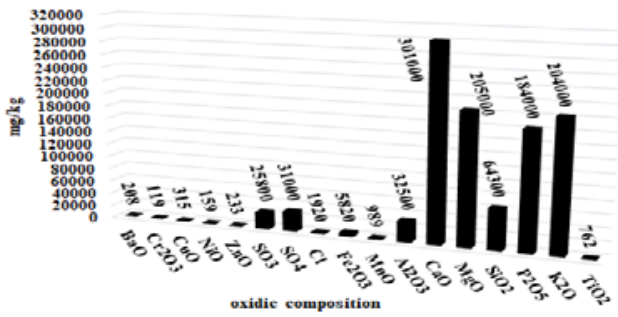

Figure 4. Oxide compozition of thermal plants fireplace slag and of thermal plants ash

We observe a weight of slag remaining on the $0.25 \mathrm{~mm}$ sieve of $56.9 \%$ and for the ash of the thermal power the fine particles with the size between 2-800 $\mu \mathrm{m}$. Depending on the composition of the processed ore, the slags are characterized by a complex chemical oxide composition; along with the main oxides: $\mathrm{CaO}, \mathrm{MgO}, \mathrm{P}_{2} \mathrm{O}_{5}$ and $\mathrm{K}_{2} \mathrm{O}$, they also contain small amounts of $\mathrm{Al}_{2} \mathrm{O}_{3}$ and $\mathrm{SiO}_{2} \mathrm{MnO}, \mathrm{TiO}_{2}, \mathrm{P}_{2} \mathrm{O}_{5}$, $\mathrm{Cr}_{2} \mathrm{O}_{3}$, etc. Therefore, the crystalline phases of the blast furnace slag represent a mixture of silicates, silico-alumina and, as the case may be, calcium and magnesium aluminates, as well as very small amounts of oxidic-silcate combinations in particular with iron, titanium, manganese; it is also noted the presence of small amounts of sulphides and combinations with phosphorus - phosphates and phosphosilicates.

\section{S4- Sunflower husks seeds ash (from thermal plants)}

Because of the storage conditions and for this type of waste, it was necessary to perform the drying operation and determine the total moisture $\mathrm{W}_{\mathrm{t}}$ according to the relation (1), after which the resulting ash at the seed husks burning was subjected to 


\section{INTERNATIONAL SYMPOSIUM "THE ENVIRONMENT AND THE INDUSTRY", SIMI 2018, PROCEEDINGS BOOK}

the sifting operation and determination of the granulometric distribution Figure 5a. Also, the ash resulted from the burning process, was analyzed from the point of view of the oxide composition shown in Figure $5 \mathrm{~b}$.

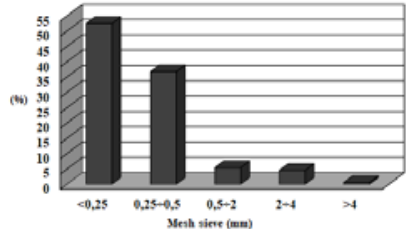

Figure 5. (a) granlometric distribution; (b) oxide composition for the resulting ash from the burning of sunflower husks seeds

The granulometric distribution for this type of waste has a large proportion with the material passed through the sieve of $0.25 \mathrm{~mm}$, namely - 50.5\%. Also, a large proportion of the material was also determined on the $0.25 \mathrm{~mm}$ sieve $-36.8 \%$, while the other quantities were lower. The ash resulting from the burning of seed husks is a powder whose oxide composition presents $\mathrm{CaO}$ in a higher amount but also $\mathrm{K}_{2} \mathrm{O}$, $\mathrm{MgO}, \mathrm{SiO}_{2}$ and $\mathrm{P}_{2} \mathrm{O}_{5}$ in smaller quantities, as shown in Figure 5b. In order to obtain ash-based oxide composite materials resulting from the burning of sunflower seed husks, the hydration process must be activated to provide an adequate kinetics as well as an adequate basicity of the system. So, the presence of the oxides shown above may influence the binder system and, of course, the obtaining of the composite material.

\section{S5- Metallic waste smelting slag}

Due to the very high temperature of the slag obtained from the electrical melting of metallic wastes, cooled with water, which means a sudden cooling with pore formation on the surface of the material. It is a property acquired for smelting slag which can have an advantage in terms of phonic wave absorption, because the porosity of a material influences in a positive sense the absorption coefficient of the sound waves. The smelting slag is a high density, hardness and porosity material, which is in the form of large boulders. Thus, it was necessary the grinding process as a first step, then sieving, to determine the granulometric distribution shown in Figure 6a and the oxidic composition shown in Figure 6b.
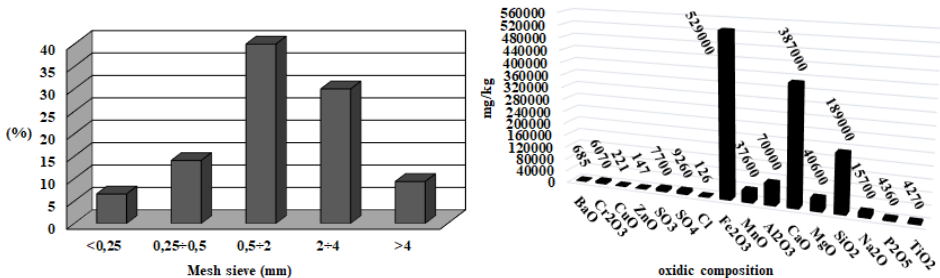

Figure 6. (a) granlometric distribution; (b) oxide composition for the metallic waste smelting slag

A granulometric weight with a maximum of $0.5-2.00 \mathrm{~mm}$ of approximately $40 \%$ was observed. Also, the granulometric fraction approximately to $2.00-4.00 \mathrm{~mm}$ is 


\section{INTERNATIONAL SYMPOSIUM "THE ENVIRONMENT AND THE INDUSTRY", SIMI 2018, PROCEEDINGS BOOK}

present in proportion of $30 \%$. The fine fractions were by $0.25-0.5 \mathrm{~mm}$ and present in proportions lower than $6.6 \%$ and $14,1 \%$, respectively, similar to coarse fractions over $4.00 \mathrm{~mm}$. This granulometric distribution, with a significant proportion of mono-grain fractions of $0.5-2.00 \mathrm{~mm}$ and $2.00-4.00 \mathrm{~mm}$, respectively, can give the composite material a uniformity, high porosity structure and can give the composite good sound-absorbing capacity. The slag resulting from the melting of metallic wastes is a by-product of melting arc. The oxide composition, seen in Figure 6b, shows a higher amount of $\mathrm{Fe}_{2} \mathrm{O}_{3}$ followed by $\mathrm{CaO}$ and $\mathrm{SiO}$ as well as $\mathrm{MgO}, \mathrm{Al}_{2} \mathrm{O}_{3}$, $\mathrm{MnO}$ and $\mathrm{Na}_{2} \mathrm{O}$ in smaller quantities.

\section{S6-Domestic sterile wastes}

It is a mixture of household wastes. The sample was brought to the laboratory after sterilization at $120^{\circ} \mathrm{C}$. Due to the storage conditions it was necessary to carry out the drying operation and the determination of the total humidity; the material was screened by the granulometric distribution shown in Figure 7a. Also in Figure $7 \mathrm{~b}$ is the oxidic composition of this type of waste.
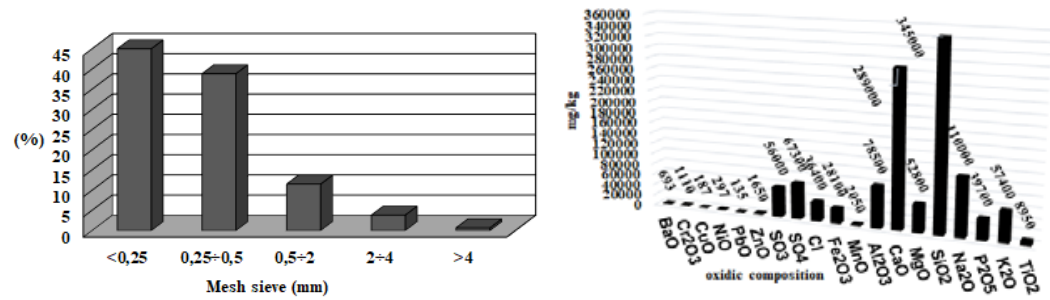

Figure 7 (a) Granulometric distribution; (b) the oxidant composition for domestic waste.

From Figure 7a, a very small amount of coarse remaining material on the $4 \mathrm{~mm}$ sieve $(0.7 \%$ of the entire amount of sieve material) is observed. On the other site, the amount of sieve material increases, so that it passed the $0.25 \mathrm{~mm}$ sieve, represents a quantity of about $45.2 \%$. The sterylated domestic waste sample, and studied in terms of the oxide composition, contains a larger amount of oxides such as: $\mathrm{SiO}_{2}, \mathrm{CaO}$, $\mathrm{Na}_{2} \mathrm{O}, \mathrm{Al}_{2} \mathrm{O}_{3}$ and $\mathrm{K}_{2} \mathrm{O}$. Also, anions of the type of $\mathrm{SO}_{4}{ }^{2-}, \mathrm{SO}_{3}{ }^{2-}$ were identified in the composition of this waste. The selected samples were identified for the production of composite materials with phono absorbing properties, were also analyzed in terms of apparent porosity. In order to obtain composite materials where the absorption of sound waves to be hight, it is necessary to obtain materials with higher porosity. Thus, Figure 8 shows the result of the determination of the apparent porosity of the analyzed samples. 


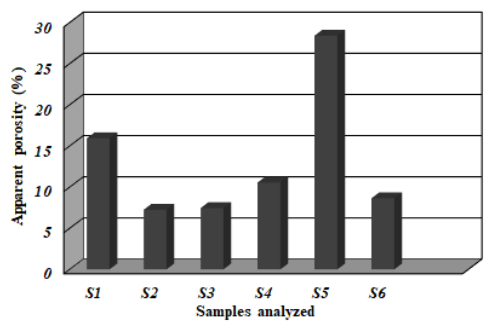

Figure 8. The aparent porosity of waste samples: S1- Wooden waste;S2- Thermal plants fireplace slag; S3- Thermal plants ash; S4- Sunflower husks seeds ash; S5Metallic waste smelting slag; S6- Domestic sterile wastes

The porosity is the principle property that gives composite material the ability to absorb sound waves. The formation of voids on the surface and in the depth of the sample influences the retention of the sound waves and implicitly the reduction of the sound pressure level. As a result of the apparent porosity, it is as certained that: for the metallic waste smelting slag, a good apparent porosity has been obtained, so that the use of this type of waste by incorporating it into the oxide matrix can give the composite material a good sound waves. absorption capacity. The same as S1wooden waste and S4- sunflower husks seeds ash. can be used as reinforcement material both in the oxide matrix and in the polymer matrix.

\section{Conclusions}

In this paper were selected and characterized from a microstructural and chemical point of view six different types of potentially usable wastes for obtaining phonoabsorbing composite materials: S1- wooden waste; S2- thermal plants fireplace slag; S3- thermal plants ash; S4- sunflower husks seeds ash; S5- metallic waste smelting slag; S6- domestic sterile wastes. The porosity is the principle property that gives composite material the capacity to absorb sound waves, while particle sizes (based on granulometric test results) can provide information about the possibility of using wastes as reinforcement material and/or binder. The possibility of using oxidic waste as a binder for the preparation of composite materials is evidenced by the proportion in which $\mathrm{CaO}, \mathrm{SiO}_{2}, \mathrm{Al}_{2} \mathrm{O}_{3}, \mathrm{MgO}$. Based on the obtained results, we can conclude that: i) wood wastes can be successfully used as reinforcement materials; ii) as well as the thermal plants fireplace slag and metallic waste smelting slag can be used as reinforcement materials due to porosity and granulometry; iii) the fine fractions of the other wastes can be used in binder matrix for obtaining oxide composite materials.

The studies will be continue by conducting experiments to obtain composite materials and testing their absorption capacity.

\section{Acknowledgements}

This work would not have been possible without the financial support of the Romanian Nucleu Programme. 


\section{INTERNATIONAL SYMPOSIUM "THE ENVIRONMENT AND THE INDUSTRY", SIMI 2018, PROCEEDINGS BOOK}

\section{References}

Bucur, E \& Danet, A 2016, 'Particulate matter and polycyclic aromatic hydrocarbon air pollution in areas of Bucharest with heavy road traffic', Revista de Chimie, vol. 67, no 4, pp. 621-625.

Bratu, M, Ovidiu, D, Ovidiu, V, Ioan, R \& Pascu, LF 2016, 'Research on attenuation of sound waves by using panels made of composite materials', Roumanian Journal of Materials, vol. 46, no.1, pp. 121-126.

Danciulescu, V, Bucur, E, Pascu, LF, Vasile, A \& Bratu, M 2015, 'Correlations between noise level and pollutants concentration in order to assess the level of air pollution induced by heavy traffic', Journal of Environmental Protection and Ecology, vol. 16, no. 3, pp. 815-823.

Danciulescu, V, Vasile, A, Pascu, LF, Stanescu, B \& Nicolescu, I 2017, 'The evaluation of the levels of greenhouse gases due to activities carried out on a livestock farm', Revista de Chimie, vol. 68, no. 8, pp 1700-1703.

Directive 2008/98 / EC on waste and repealing certain Directives.

Emergency Ordinance 195/2005 on environmental protection.

Guta, D, Cuciureanu, A, Kim, L \& Arama, M 2017, 'The assessement of dangerousnessof waste. Case study: Waste originating from drilling muds', $20^{\text {th }}$ International Symposium "The Environment and The Industry", SIMI 2017, National Research and Development Institute for Industrial Ecology ECOIND, Bucharest, pp. 189-194.

http://www.mmediu.ro/app/webroot/uploads/files/RM SEA PNGD v4.pdf,

[November 2017].

http://www.mmediu.ro/beta/domenii/gestionarea-deseurilor/, [February 2018].

Law 211 of 15 November 2011 on Waste Management.

Lilliana, AG, Ger, M \& William, H 2013, 'Solid waste management challenges for cities in developing countries', Journal of Waste Management, vol. 33, pp. 220-232.

Minghua, Z, Fan, X, Alberto, R, He, Q, Federico, V, Liu, B, Alessandro, G \& Liu, Yi 2009, 'Municipal solid waste management in Pudong New Area, China', Journal of Waste Management, vol.29 , pp. 1227-1233.

Petrescu, M, Bucur, E, Diodiu, R, Bratu, M, Serbanescu, A \& Barbu, M 2017, 'Chemical characterization of wet depositions in urban and rural area', $20^{\text {th }}$ International Symposium “The Environment and The Industry”, SIMI 2017, National Research and Development Institute for Industrial Ecology ECOIND, Bucharest, pp. 213-220.

Serbanescu, A, Barbu, M, Nicolescu, I \& Bucur, E 2017, 'Interdependence between total organic carbon content and heating value of sewage sludge samples', $20^{\text {th }}$ International Symposium “The Environment and The Industry”, SIMI 2017, National Research and Development Institute for Industrial Ecology ECOIND, Bucharest, pp. 272-278.

Stoleriu, S \& Teoreanu, I 2006, 'Hardening processes of binding systems free of Portland cement', Revista de Chimie, vol. 57, no. 6, pp. 590-593.

Stoleriu, S, Teoreanu, I \& Bratu, M 2004, 'Activator role in strengthening cementoid - puzzolan binder systems', Romanian Journal of Materials, vol. 34, no.3, pp. 216-225.

SR ISO 5264-1995 Solid mineral fuels. Coal. Determination of humidity. 


\section{INTERNATIONAL SYMPOSIUM "THE ENVIRONMENT AND THE INDUSTRY", SIMI 2018, PROCEEDINGS BOOK}

SR ISO 2591-1:2003 Sieve analysis. Part 1: Sieving method in metal and perforated sheets.

SR EN-933-1:2002 Tests for determining the geometric characteristics of aggregates Part 1: Determination of granularity. Sieve granulometry analysis.

SR ISO 13320-1:2001 Particle Size Analysis - Laser Diffraction Method.

SR 15309:2007 Waste and Soil Characterization. Determination of elemental composition by X-ray fluorescence.

SR EN 993-1:1997 Test methods for dense shaped refractory products. Part 1: Determination of apparent density of open porosity and total porosity.

Teoreanu, I \& Stoleriu, S 2002, 'Cements free of Portland clinkers', Romanian Journal of Materials, vol. 32, no, 3, pp. 190-196.

Teoreanu, I, Volceanov, A Stoleriu, S 2005, 'Non Portland cements and derived materials', Cement and Concrete Composites, vol. 27, no.6, pp. 650-660. 